\title{
REVIEWS
}

\section{Microbial Changes in Subgingival Plaque During Orthodontic Treatment - Literature Review}

\section{Zmiany mikrobiologiczne w płytce poddziąsłowej podczas leczenia ortodontycznego - przegląd piśmiennictwa}

\author{
Department of Orthodontics, Warsaw Medical University, Warsaw, Poland
}

A - research concept and design; B - collection and/or assembly of data; $\mathbf{C}$ - data analysis and interpretation;

$\mathbf{D}$ - writing the article; $\mathbf{E}$ - critical revision of the article; $\mathbf{F}$ - final approval of article

\begin{abstract}
Dental plaque is considered one of the factors inducing oral cavity diseases such as caries, periodontitis, gingivitis and peri-implantitis. Treatment with orthodontic appliances is related to a change of physiological properties within the oral cavity. Hampered hygiene as well as an increased number of retentive sites result in increased accumulation of dental plaque as well as a slowing down of the spontaneous physiological processes of tooth cleaning. As a consequence, so-called orthodontic biofilm occurs that creates a range relation with other structures of the oral cavity. For over 100 years, research has been conducted aimed at an explanation of the influence of bacteria on the etiopathogenesis of periodontal diseases. Many authors have stated that changes in periodontal tissues might occur during orthodontic treatment. There are few publications referring to young children (9-14 years of age); the number of comparisons of patients treated with fixed and removable orthodontic appliances are also scarce. The objective of this paper is an attempted answer to the question whether orthodontic appliances may affect the number of bacteria which cause periodontal diseases? (Dent. Med. Probl. 2016, 53, 1, 118-124).
\end{abstract}

Key words: orthodontic treatment, subgingival plaque, microbial changes.

Słowa kluczowe: leczenie ortodontyczne, płytka poddziąsłowa, zmiany mikrobiologiczne.

The formation of dental plaque is a multistage process beginning with the adsorption of salivary protein to the cleaned surface of the tooth. In this way the so-called acquired enamel pellicle is formed [1], which after 1-2 days is inhabited by oral cavity bacteria. The colonizing bacteria create 1-20 layers, with Gram-positive cocci (Streptococcus spp.) prevailing. Towards the apex, the plaque is also inhabited by filamentous and fusiform bacteria and a very small number of Gram-negative cocci. The bacteria inhabiting this layer are classified as aerobes and facultative anaerobes (obligate anaerobes are very few) [2].

Further development of the plaque is characterized by an increased number of Gram-negative bacteria of coccus shape, and Gram-positive and Gram-negative bacilli as well as fusiform and filamentous bacteria $[1,3]$. The biofilm is charac- terized by an increase of the number of layers, up to approximately 200-300, as well as a rise in the number of anaerobes. Stage 3 is plaque maturation. The number of layers amounts to over 300 , the thickness of the plaque is $0.5 \mathrm{~mm}$ and it is visible with the naked eye. The chemical composition of the plaque changes, spirochetes and flagellated bacteria occur. The population of Gram-negative bacteria also increases.

For over 100 years, research has been conducted aimed at an explanation of the influence of bacteria on the etiopathogenesis of periodontal diseases. The gingival sulcus is inhabited by over 500 bacteria species but, according to the research, only some of them play a significant role in the initiation and course of a periodontal disease [4]. A normal gingival sulcus contains a prevalent number of Gram-positive bacteria whereas in gingival pockets 
Gram-negative bacteria prevail [5, 6]. In the 1980s, the research focused on identification of a single bacterial species which would induce periodontal diseases [6]. Contrary to this hypothesis there was another one suggested - a non-specific plaque theory stating that all the bacteria in dental plaque are involved in causing periodontal diseases [7]. In the 1990s, the specific plaque hypothesis presented by Socransky [8] discarded the previous two opposite hypotheses. According to Socransky's theory, inflammation of periodontal tissues is induced by bacterial complexes comprising some specific species. These bacteria include Gram-negative anaerobes: Porphyromonas gingivalis (P.g.), Prevotella intermedia (P.i.), Tannerella forsythia (T.f.), Aggregatibacter actinomycetemcomitans (A.a), Capnocytophaga ochracea, Eikenella corrodens (E.c.), Campylobacter rectus (C.r.), Fusobacterium nucleatum (F.n.), and Treponema denticola (T.d.). The research conducted in the last 25 years has demonstrated that the presence of the above-mentioned bacteria indicates a positive correlation with clinical symptoms such as gingival inflammation, and clinical loss of the connective tissue attachment as well as increased depth of the gingival pocket [6]. Socransky [8] demonstrated that bacteria related to periodontal diseases form several complexes: red, orange, species associated with the orange complex, green, and the Aggregatibacter actinomycetemcomitans (A.a.) complex, which show different pathogenicity. Bacteria of the red complex demonstrate a powerful correlation with the depth of gingival pockets. The composition of complexes is presented in table 1 . The complexes are related to one another by numerous nutritional dependences as well as defense mechanisms.

The research demonstrated that the highest pathogenicity was shown by the Aggregatibacter actinomycetemcomitans complex and species included in the red complex such as Treponema denticola, Porphyromonas gingivalis, and Tannerella forsythia. Whereas the role of the orange complex is to prevent formation of the red complex, bacteria included in the red complex are believed to be marker bacteria of chronic periodontitis. Ximénez-Fyvie et al. [9] analyzed the difference between the composition of supragingival and subgingival plaque in patients with periodontal diseases. A total of 1170 plaque samples were collected for the qualitative and quantitative analysis of 40 bacterial species. A DNA probe as well as a DNA-DNA hybridization technique were used in this study to identify bacterial genomes. All the analyzed bacteria were found - 40 species. The Aggregatibacter actinomycetemcomitans were the most commonly isolated bacteria from both the plaque types, the supragingival and subgingival, although in the subgingival plaque $A$. naeslundii was found more often. The prevalent complexes in the supragingival plaque compared to the subgingival plaque were the green and yellow complexes as well as the complex with Aggregatibacter actinomycetemcomitans, whereas in the subgingival plaque the red and orange complex prevailed. According to the authors mentioned above, the supragingival plaque may constitute a source of infection as well as secondary infection of the periodontal tissues (Table 1).

For many years research has been conducted to develop a test that would allow effective and fast detection of bacteria and their metabolites in the gingival pockets. The available tests are based on methods such as microscopic observation of the colonies, bacterial cultures grown in a medium, immunological, enzymatic, and genetic methods [6]. Until now, no perfect method has been de-

Table 1. Periopathogenic complexes, their bacterial composition and pathogenicity [9-11]

\begin{tabular}{|l|l|l|}
\hline Type of complex & Composition & Pathogenicity \\
\hline Orange complex & $\begin{array}{l}\text { Prevotella intermedia } \\
\text { Parvimonas micra } \\
\text { Fusobacterium nucleatum } \\
\text { Campylobacter rectus } \\
\text { Eubacterium nodatum }\end{array}$ & moderate to high pathogenicity \\
\hline $\begin{array}{l}\text { Species associated } \\
\text { with the orange complex }\end{array}$ & $\begin{array}{l}\text { Streptococcus gordonii } \\
\text { Streptococcus intermedius } \\
\text { Streptococcus sanguis }\end{array}$ & moderate to high pathogenicity \\
\hline Red complex & $\begin{array}{l}\text { Treponema denticola, Porphyromonas gingivalis } \\
\text { Tannerella forsythia }\end{array}$ & high pathogenicity \\
\hline Green complex & $\begin{array}{l}\text { Capnocytophaga gingivalis } \\
\text { Capnocytophaga ochracea } \\
\text { Capnocytophaga sputigena }\end{array}$ & moderate pathogenicity \\
\hline A.a. complex & Aggregatibacter actinomycetemcomitans & very high pathogenicity \\
\hline
\end{tabular}


veloped; each of the methods mentioned above has its own advantages and disadvantages. At present, the most commonly used methods are polymerase chain reaction and nucleic acid hybridization with the use of molecular probes [12]. The improvement of diagnostic tests will provide benefits for diagnostics, prognosis, and treatment of the discussed diseases. Development of effective diagnostics for gingivitis and periodontitis will facilitate the treatment of these conditions which, according to Jańczyk and Ciągło [1], are found in 93.7\% of patients aged 35-45.

The search for articles was conducted in PubMed, Science Direct and Wiley databases. Only articles published in English between 1997 and December 2013 were used. The following keywords were used in the preliminary search: „appliance" and "orthodontic treatment" and "bacteria” or "Aggregatibacter actinomycetemcomitans" or "Porphyromonas gingivalis” or "subgingival plaque” or "Prevotella intermedia” or „Tannerella forsythia" or "Treponema denticola” or „Parvimonas micra” or "Fusobacterium nucleatum” or "Campylobacter rectus". The following inclusion criteria were applied to the selected articles: clinical trial, studies in humans, removable orthodontic appliances or fixed appliances placed onto the buccal tooth surface. The exclusion criteria were: lingual orthodontic appliances, presence of other diseases (periodontal disease), examination of other bacteria and fungi (Streptococcus spp., Candida albicans).

\section{Evaluation of Pathogenic Bacteria Occurring in Subgingival Plaque in Patients Using Orthodontic Appliances}

A review of the available studies presented in Table 2 shows that interest in periopathogens occurring in gingival pockets during orthodontic treatment began at the end of the 1990s. Paolantonio et al. [13] tried to establish whether the use of a fixed orthodontic appliance may affect the increase of the number of A.actinomycetemcomitans in the subgingival plaque. The authors qualified 24 patients with a similar malocclusion for the study to collect their plaque samples. The orthodontic appliance was placed only on a single dental arch, the other one was the control arch. The samples were collected before the orthodontic appliance was placed on the arch, after 4,8 , and 12 weeks of treatment. Then the appliances were removed and after another 4 weeks further tests were carried out. The authors found increased inflammation indices as well as deteriorated oral hy- giene during the orthodontic treatment. Whereas A.a., which before treatment was isolated from the gingival pockets of the dental arch with a fixed orthodontic appliance only in one patient, was found in 19 patients after 4 weeks, in 20 patients after 8 weeks, and in 7 patients after 4 weeks of the appliance removal. In the control arch, A.a. was isolated from one place during the study. The authors concluded that the appliance on an arch promoted an increase of the number of the A.a. bacteria in the gingival pockets of orthodontically moved teeth. According to the authors, the increase of the number of the A.a. bacteria did not affect its occurrence in other locations of the oral cavity.

The development of molecular biology methods have made it possible to replace bacteria isolation with the use of culture on media with methods that are faster and more accurate, and show more sensitivity and species specificity. Ximénez-Fyvie et al. [10] compared the microbiological composition of supragingival and subgingival plaque in adults. The study groups were comprised of patients with normal periodontal tissues as well as patients with periodontitis. Forty bacterial species from the microbial plaque were analyzed with the use of specific genome DNA probes. The molars, with the third molars excluded, underwent clinical evaluation for change in gingiva color, accumulation of dental plaque, bleeding on probing, and the grade of clinical loss of connective tissue attachment as well as the depth of the gingival pocket. The study demonstrated that in both study groups the supragingival plaque contained P.g., Tannerella forsythia (T.f.) and Treponema denticola (T.d.). Whereas the subgingival plaque in subjects with a periodontal disease showed increased numbers of P.g., and Tannerella forsythia (T.f.), as well as Prevotella, Fusobacterium, Campylobacter genera, in the samples of subgingival and supragingival plaque collected from subjects with a periodontal disease, an increase of the number of the following bacteria was found: P.g., T.f., and T.d.

Sallum et al. [14] evaluated the periodontium and microbiological composition of gingival pockets in 10 patients (aged $18 \pm 1.8$ years of age) at the final stage of treatment with fixed appliances. The patients showed clinical symptoms of gingivitis. The authors analyzed 5 periopathogens (P.g., T.f., A.a., P.i., P.n.) both, in the supragingival plaque as well as the subgingival plaque. In regard of the periopathogens mentioned above, after 30 days of the fixed appliance removal, the most apparent was the decrease of the number of A.a. and T.f. The authors demonstrated improvement of the clinical condition of the gingiva in a month after 
the appliance was removed as well as a statistically significant difference in reducing the size of gingival pockets from $2.5 \mathrm{~mm} \pm 0.51$ to $1.92 \mathrm{~mm} \pm 0.42$ in patients treated with fixed orthodontic appliances. After 30 days of the appliance removal, the GI dropped from $100 \%$ to $23.3 \%$.

Different results were presented by Naranjo et al. [15]. They examined similar parameters but they conducted the study before and after 3 months of fixation of the orthodontic appliance elements on the teeth in a 30 -subject study group and 30 -subject control group. The authors did not find a statistically significant difference in the depth of gingival pockets or the clinical loss of the connective tissue attachment during the study periods. An increase of gingival indices was found as well as the plaque index 3 months after the treatment was started. Additionally, changes within the microflora of the subgingival plaque were found with an increased number of the following bacteria: Porphyromonas gingivalis, Prevotella intermedia/Prevotella nigrescens, Tannerella forsythia, and Fusobacterium species.

Ristic et al. [16], in a prospective study, compared clinical parameters (PI, GI, GBI, PD) and microbiological analysis in 32 patients aged $12-18$, treated with fixed appliances. A comparative analysis was performed before the treatment, 3 weeks, 1 month, 3 and 6 months after the treatment with a fixed appliance was started. The authors demonstrated an increase of clinical and bacteriological parameters after commencement of the treatment. Rather surprising was the observation they made, that beginning with treatment month 3 , gingival indices and plaque indices started to decrease in value. The investigators observed an increase of the number of periopathogens but they did not find a clinical loss of connective tissue attachment.

Another study by Lee et al. [17] presented an increased number of periopathogens in the subgingival plaque in patients during orthodontic treatment (17 subjects in the study group, 19 subjects in the control group). The study demonstrated increased T.f., T.d., and P.n. in subjects during orthodontic treatment. According to the authors, treatment with a fixed appliance may affect the increase of periopathogens in the subgingival plaque.

There are few published studies which evaluate the clinical parameters and provide microbiological evaluation to compare the flora of the gingival pockets of teeth with fixed bands and teeth with brackets. In one of the studies, the authors [18] assessed the periodontium in 33 patients aged 12-18. The subjects had been using orthodontic appliances for at least 6 months. The authors investigated clinical condition and evaluated subgingival flora in premolars with brackets compared to molars with cemented bands. The bands on the investigated teeth were cemented subgingivally or supragingivally. The study did not provide a comparison with a control group nor the inclusion criteria for the gingival pockets. The authors demonstrated that all the patients in the study showed $45.0 \%$ of gingival pockets smaller than $2 \mathrm{~mm}, 50.8 \%$ with a depth of $3 \mathrm{~mm}, 4.2 \%$ of pockets with a value exceeding $4 \mathrm{~mm}$ and one case exceeding $5 \mathrm{~mm}$. The difference between the deeper pockets around the teeth with bands and more shallow pockets around those with brackets was statistically significant. The PI measurement did not indicate a statistically significant difference between the groups, whereas the GI measurement showed higher values in the case of teeth with cemented bands.

Demling et al. [19] tried to clarify the influence of supragingival flora on the subgingival flora. Apart from clinical parameters (API and SBI), they evaluated the surfaces of 28 orthodontic bands in patients treated with fixed appliances. The investigators demonstrated that $16.1 \% \pm 9.2$ of the supragingival surface and $3.6 \% \pm 4.4$ of the subgingival surface was covered with biofilm. The difference was statistically significant. The biggest amount of biofilm in the subgingival zone was observed within the areas of notches in the orthodontic bands. The authors drew a conclusion that most probably the immunological response of the gingival fluid mediators inhibits bacterial adhesion to the subgingival surface of the bands.

Thornberg et al. [20] conducted an analysis of 190 subgingival plaque samples in orthodontically treated patients in 5 study periods (the mean age of the subjects was 13 years and 6 months). The subgingival plaque samples were collected before the treatment was started, after 3 months of treatment, after 6 months and after 12 months of treatment and after approximately 3 months of the fixed appliance removal. The authors analyzed the composition of the subgingival flora for periopathogenic bacteria: Aggregatibacter actinomycetemcomitans, Porphyromonas gingivalis, Prevotella intermedia, Tannerella forsythia, Eikenella corrodens, Fusobacterium nucleatum, Treponema denticola, and Campylobacter rectus. Six of the eight periopathogens (P.i., T.f., E.c., F.n., T.d., C.r.) increased considerably in treatment month 6 but the authors stated that their levels returned to the baseline values after 12 months.

Research by Kloehn and Pfeifer [21], Boyd et al. [22], and Sallum et al. [14] demonstrated that after the orthodontic appliance is placed, many patients developed generalized gingivitis regardless of the type of their malocclusion, the type of 
appliance, its components or the type of the adhesive. The occurrence of new retentive sites promotes increased bacterial plaque accumulation. There are available studies referring to monitoring the indices of periodontium condition (Plaque Index, Gingival Index, PD), whereas the studies investigating the microflora of gingival pockets are fewer and the research comparing the condition of the periodontium and the microflora of the gingival pockets in patients who are using fixed and removable orthodontic appliances is almost non-existent $[14,23,24]$.

A systematic analysis of the literature showed that the clinical parameters of periodontium condition in patients using orthodontic appliances most commonly investigated in the research of

Table 2. Analysis of publications with identification of the investigated clinical parameters referring to the condition of periodontal tissues, bacterial species, and diagnostic methods in orthodontically treated patients

\begin{tabular}{|c|c|c|c|c|c|c|}
\hline & Year & Authors & $\begin{array}{l}\text { Clinical } \\
\text { parameters }\end{array}$ & $\begin{array}{l}\text { Bacterial } \\
\text { species }\end{array}$ & $\begin{array}{l}\text { Diagnostic } \\
\text { method }\end{array}$ & Results \\
\hline 1. & 1997 & $\begin{array}{l}\text { Paolantonio } \\
\text { et al. [13] }\end{array}$ & $\begin{array}{l}\text { GBI, PD, } \\
\text { CAL }\end{array}$ & A.a. & $\begin{array}{l}\text { Microbial } \\
\text { culture }\end{array}$ & $\begin{array}{l}\text { increase of bacteria A.a. in gingival } \\
\text { pockets }\end{array}$ \\
\hline 2. & 1999 & $\begin{array}{l}\text { Paolantonio } \\
\text { et al. [25] }\end{array}$ & $\begin{array}{l}\text { GBI, PD, } \\
\text { CAL }\end{array}$ & A.a. & $\begin{array}{l}\text { Microbial } \\
\text { culture }\end{array}$ & $\begin{array}{l}\text { placement of orthodontic appliances } \\
\text { promotes the subgingival growth } \\
\text { of } A . a \text {. }\end{array}$ \\
\hline 3. & 2000 & $\begin{array}{l}\text { Ximénez-Fy- } \\
\text { vie et al. [10] }\end{array}$ & - & $\begin{array}{l}40 \text { bacterial spe- } \\
\text { cies }\end{array}$ & DNA probes & $\begin{array}{l}\text { differences between supra and } \\
\text { subgingival plaque were in the pro- } \\
\text { portions and levels of Actinomyces, } \\
\text { "orange" and "red" complex species }\end{array}$ \\
\hline 4. & 2002 & Asai et al. [26] & - & T.d., T.v., T.m. & $\begin{array}{l}\text { Real-time } \\
\text { PCR }\end{array}$ & $\begin{array}{l}\text { T.d. cells were detected in plaque } \\
\text { samples from deep pockets }\end{array}$ \\
\hline 5. & 2004 & $\begin{array}{l}\text { Sallum } \\
\text { et al. [14] }\end{array}$ & PI, GI, PD & $\begin{array}{l}\text { P.g., T.f., A.a., P.i., } \\
\text { P.n. }\end{array}$ & PCR & $\begin{array}{l}\text { reduction of sites positive for A.a. and } \\
\text { T.f. after appliance removal }\end{array}$ \\
\hline 6. & 2005 & Lee et al. [17] & $\begin{array}{l}\text { PI, GI, PD, } \\
\text { CAL, BOP }\end{array}$ & $\begin{array}{l}\text { A.a., T.d., P.g., } \\
\text { T.f., P.n., P.i. }\end{array}$ & $\begin{array}{l}16 \mathrm{~S} \text { rDNA } \\
\text { PCR }\end{array}$ & $\begin{array}{l}\text { T. forsythia, T. denticola, and } P . n i- \\
\text { grescens were significantly more com- } \\
\text { mon in the samples obtained from } \\
\text { the orthodontic patients }\end{array}$ \\
\hline 7. & 2006 & $\begin{array}{l}\text { Naranjo } \\
\text { et al. [15] }\end{array}$ & $\begin{array}{l}\text { PI, GI, PD, } \\
\text { CAL, BOP, }\end{array}$ & $\begin{array}{l}\text { P.g., P.i., P.n., T.f., } \\
\text { Fusobacterium sp. }\end{array}$ & $\begin{array}{l}\text { Microbial } \\
\text { culture }\end{array}$ & $\begin{array}{l}\text { bracket placement influences the } \\
\text { colonization of important periodon- } \\
\text { topathic bacteria }\end{array}$ \\
\hline 8. & 2008 & $\begin{array}{l}\text { Ristic } \\
\text { et al. [16] }\end{array}$ & $\mathrm{PD}, \mathrm{CAL}$ & P.i., A.a., P.g., F.n. & PCR & $\begin{array}{l}\text { total number of periodontopathic } \\
\text { anaerobes increased during } 3 \text { moths } \\
\text { treatment with fixed appliances }\end{array}$ \\
\hline 9. & 2009 & $\begin{array}{l}\text { Thornberg } \\
\text { et al. [20] }\end{array}$ & - & $\begin{array}{l}\text { A.a., P.g., P.i., T.f., } \\
\text { E.c., F.n., T.d., } \\
\text { C.r. }\end{array}$ & DNA probes & $\begin{array}{l}\text { for } 6 \text { (P.i., T.f., E.c., F.n., T.d., C.r.) of } \\
\text { the } 8 \text { pathogens, the percentages of } \\
\text { subjects with high pathogen counts } \\
\text { increased after } 6 \text { months of fixed ap- } \\
\text { pliance treatment }\end{array}$ \\
\hline 10. & 2009 & Choi et al. [27] & - & $\begin{array}{l}\text { A.a., T.f., C.r., E.c., } \\
\text { P.g., P.i., P.n., T.d. }\end{array}$ & 16 rRNA PCR & $\begin{array}{l}\text { reduction of sites positive for C.r. and } \\
\text { E.c. after appliance removal }\end{array}$ \\
\hline 11. & 2009 & $\begin{array}{l}\text { Demling } \\
\text { et al. [19] }\end{array}$ & $\mathrm{BOP}, \mathrm{PD}, \mathrm{PI}$ & A.a., P.g. & PCR & $\begin{array}{l}\text { prevalence of } A . a . \text { and P.g. remained } \\
\text { unchanged after } 3 \text { months of fixed } \\
\text { appliance treatment }\end{array}$ \\
\hline 12. & 2009 & $\begin{array}{l}\text { Demling } \\
\text { et al. [28] }\end{array}$ & API, SBI & $\begin{array}{l}\text { Biofilm occurren- } \\
\text { ce on the ortho- } \\
\text { dontic bands }\end{array}$ & $\begin{array}{l}\text { Electron mi- } \\
\text { croscopy }\end{array}$ & $\begin{array}{l}\text { no mature subgingival biofilm was } \\
\text { found on the orthodontic bands }\end{array}$ \\
\hline 13. & 2010 & $\begin{array}{l}\text { Atassi and } \\
\text { Awartani [29] }\end{array}$ & $\begin{array}{l}\text { PI, OPI, } \\
\text { GBI }\end{array}$ & - & $\begin{array}{l}\text { Clinical exa- } \\
\text { mination }\end{array}$ & $\begin{array}{l}\text { PI and OPI were high with mean } \\
\text { scores }\end{array}$ \\
\hline 14. & 2010 & Kim et al. [18] & PI, BOP & 37 species & $\begin{array}{l}\text { DNA-DNA } \\
\text { hybridization }\end{array}$ & $\begin{array}{l}\text { deeper pockets were found around } \\
\text { orthodontic bands }\end{array}$ \\
\hline 15. & 2011 & $\begin{array}{l}\text { van Gastel } \\
\text { et al. [30] }\end{array}$ & $\mathrm{PD}, \mathrm{BOP}$ & $\begin{array}{l}\text { Aerobe/anaerobe } \\
\text { ratio }\end{array}$ & $\begin{array}{l}\text { Bacterial cul- } \\
\text { tures }\end{array}$ & $\begin{array}{l}\text { relatively more anaerobes at } \mathrm{T} 2 \\
\text { (bracket removal) compared to } \mathrm{T} 1 \\
\text { (baseline) }\end{array}$ \\
\hline
\end{tabular}


Table 2 (cont.). Analysis of publications with identification of the investigated clinical parameters referring to the condition of periodontal tissues, bacterial species, and diagnostic methods in orthodontically treated patients - cont.

\begin{tabular}{|l|l|l|l|l|l|l|}
\hline & Year & Authors & $\begin{array}{l}\text { Clinical } \\
\text { parameters }\end{array}$ & $\begin{array}{l}\text { Bacterial } \\
\text { species }\end{array}$ & $\begin{array}{l}\text { Diagnostic } \\
\text { method }\end{array}$ & Results \\
\hline 16. & 2013 & $\begin{array}{l}\text { Montaldo } \\
\text { et al. [31] }\end{array}$ & & $\begin{array}{l}\text { P.g., P.i., A.a., T.f., } \\
\text { T.d. }\end{array}$ & PCR & $\begin{array}{l}\text { positivity for T.f. was correlated to } \\
\text { sampling time and oral hygiene mo- } \\
\text { tivation }\end{array}$ \\
\hline 17. & 2013 & $\begin{array}{l}\text { Nalçac1 et al. } \\
\text { [32] }\end{array}$ & PI, GI, BOP & $\begin{array}{l}\text { Supragingival } \\
\text { plaque }\end{array}$ & $\begin{array}{l}\text { Clinical exa- } \\
\text { mination }\end{array}$ & $\begin{array}{l}\text { bracket has an effect on periodontal } \\
\text { status }\end{array}$ \\
\hline 18. & 2013 & $\begin{array}{l}\text { Ghijselings } \\
\text { et al. [33] }\end{array}$ & $\begin{array}{l}\text { GCF, BOP, } \\
\text { PD }\end{array}$ & $\begin{array}{l}\text { Aerobe/anaerobe } \\
\text { ratio }\end{array}$ & $\begin{array}{l}\text { Clinical exa- } \\
\text { mination }\end{array}$ & $\begin{array}{l}\text { placement of fixed appliances has an } \\
\text { impact on periodontal parameters }\end{array}$ \\
\hline 19. & 2013 & $\begin{array}{l}\text { Torlakovic } \\
\text { et al. [34] }\end{array}$ & PI, GI & $\begin{array}{l}\text { Occurrence of pe- } \\
\text { riopathogens and } \\
\text { cariopathogens }\end{array}$ & $\begin{array}{l}\text { Clinical exa- } \\
\text { mination }\end{array}$ & $\begin{array}{l}\text { not all parameters were normali- } \\
\text { zed 2 years post-treatment }\end{array}$ \\
\hline 20. & 2013 & $\begin{array}{l}\text { Baka et al. [35] } \\
\text { PI, PD, BOP }\end{array}$ & $\begin{array}{l}\text { S.m., S.s., L.c., } \\
\text { L.a. }\end{array}$ & PCR-real time & $\begin{array}{l}\text { clinical parameters and the microor- } \\
\text { ganisms showed increases from base- } \\
\text { line to 3 months after bonding }\end{array}$ \\
\hline 21. & 2013 & $\begin{array}{l}\text { Ireland } \\
\text { et al. [36] }\end{array}$ & - & $\begin{array}{l}\text { P.g, T.f., E.n., C.r., } \\
\text { P.m. }\end{array}$ & PCR & $\begin{array}{l}\text { orthodontic treatment may cause su- } \\
\text { stained changes in plaque microbiotas }\end{array}$ \\
\hline
\end{tabular}

1970s were as follows: PI, GI, BOP, and PD. Other parameters assessed in the studies included CAL, GBI (Gingival Bleeding Index), OPI (OrthoPlaque Index), etc (Table 2).

\section{Conclusion}

As the above literature review implies, many questions still remain unanswered but the increase of periopathogens during treatment with orthodontic appliances is probable. The literature review demonstrated that they were often the red complex bacteria, which were perceived as the ones showing high pathogenicity. Many authors stated that changes in periodontal tissues might occur during orthodontic treatment. There are few publications referring to young children (9-14 years of age); the number of comparisons of patients treated with fixed and removable orthodontic appliances are also scarce. The comparison of periodontal tissue condition and oral hygiene in children treated with fixed and removable appliances would allow implementation of preventive and follow-up measures during the therapy as well as provide an answer to a question whether subgingival microbial flora diagnostic testing is justified to prevent periodontal complications.

\section{References}

[1] Jańczuk Z., CiągŁo A.: Introduction to epidemiology of masticatory system conditions. Medical Education Centre, Warsaw, 1999 [in Polish].

[2] Stots J.: Microflora in the healthy gingival sulcus in man. Scand. J. Dent. Res. 1977, 85, 247-254.

[3] Listgarten M.A.: Structure of the microbial flora associated with periodontal health and disease in man. J. Periodontol. 1976, 47, 1-18.

[4] Socransky S.S., HAffajeE A.D.: The bacterial etiology of destructive periodontal disease: current concepts. J. Periodontol. 1992, 63, 322-331.

[5] Clinical Periodontology. Ed.: Wierzbicka M., Part 1, Sanmedia, Med Tour Press International Publishing. Warsaw 1992 [in Polish].

[6] Eley B.M., Soory M., Manson J.D.: Periodontology. Elsevier Urban \& Partner Publishing, Wrocław, 2011 [in Polish].

[7] Theilade E.: The non-specific theory in microbial etiology of inflammatory periodontal diseases. J. Clin. Periodontol. 1986, 13, 905-911.

[8] Socransky S.S.: Microbial complexes in subgingival plaque. J. Clin. Periodontol. 1998, 25, 134-144.

[9] Ximénez-Fyvie L.A., Haffajee A.D., Socransky S.S.: Comparison of the microbiota of supra- and subgingival plaque in health and periodontitis. J. Clin. Periodontol. 2000, 27, 648-657.

[10] Ximénez-Fyvie L.A., Haffajee A.D., Socransky S.S.: Microbial composition of supra- and subgingival plaque in subjects with adult periodontitis. J. Clin. Periodontol. 2000, 27, 722-732.

[11] Sbordone L., Bortolaia C.: Oral microbial biofilms and plaque-related diseases: microbial communities and their role in the shift from oral health to disease. Clin. Oral Investig. 2003, 7, 181-188.

[12] Krawczyk B.: Molecular diagnostics in hospital infections. Post. Mikrobiol. 2007, 46, 367-378 [in Polish]. 
[13] Paolantonio M., Pedrazzoli V., di Murro C., di Placido G., Picciani C., Catamo G., De Luca M., PiaccoLOMINI R.: Clinical significance of Actinobacillus actinomycetemcomitans in young individuals during orthodontic treatment. J. Clin. Periodontol. 1997, 24, 610-617.

[14] Sallum E.J., Nouer D.F., Klein M.I., Goncalves R.B., Machion L., Sallum A.W.: Clinical and microbiologic changes after removal of orthodontic appliances. Am. J. Orthod. Dentofacial. Orthop. 2004, 126, 363-366.

[15] Naranjo A.A., Triviño M.L., Jaramillo A., Betancourth M., Boterob J.E.: Changes in the subgingival microbiota and periodontal parameters before and 3 months after bracket placement. Am. J. Orthod. Dentofacial. Orthop. 2006, 130, 17-22.

[16] Ristic M., Vlahovic-Svabic M., Sasic M., Zelic O.: Effects of orthodontic appliances on subgingival microflora. Int. J. Dent. Higiene 2008, 6, 129-136.

[17] Lee S.M., Yoo S.Y., Kim H.S., Kim K.W., Yoon Y.J., Lim S.H., Shin H.Y., Kook J.K.: Prevalence of putative periodontopathogens in subgingival dental plaques from gingivitis lesions in Korean orthodontic patients. J. Microbiol. $2005,43,260-265$.

[18] Kim K., Heimisdottir K., Gebauer U., Persson G.R.: Clinical and microbiological findings at sites treated with orthodontic fixed appliances in adolescents. Am. J. Orthod. Dentofacial. Orthop. 2010, 137, 223-228.

[19] Demling A., Demling C., Schwestka-Polly R., Stiesch M., Heuer W.: Influence of lingual orthodontic therapy on microbial parameters and periodontal status in adults. Eur. J. Orthod. 2009, 31, 638-642.

[20] Thornberg M.J., Riolo C.H.S., Bayiri B., Riolo M.L., Van Tubergen E.A., Kulbersh R.: Periodontal pathogen level in adolescents before, during, after fixed orthodontic appliance therapy. Am. J. Orthod. Dentofacial. Orthop. 2009, 135, 95-98.

[21] Kloehn J.S., Pfeifer J.S.: The effect of orthodontic treatment on the periodontium. Angle Orthod. 1974, 44, 127-134.

[22] Boyd R., Leggott P., Quinn R., Eakle W., Chambers D.: Periodontal implications of orthodontic treatment in adults with reduced or normal periodontal tissues versus those of adolescents. Am. J. Orthod. Dentofacial. Orthop. 1989, 96, 191-198.

[23] ZACHRISson B.U.: Cause and prevention of injuries to teeth and supporting structures during orthodontic treatment. Am. J. Orthod. 1976, 69, 285-300.

[24] Zachrisson S., Zachrison B.U.: Gingival condition associated with orthodontic treatment. Angle Orthod. 1972, 42, 26-34.

[25] Paolantonio M., Festa F., di Placido G., D’Attilio M., Catamo G., Piccolomini R.: Site-specific subgingival colonization by Actinobacillus actinomycetemcomitans in orthodontic patients. Am. J. Orthod. Dentofacial. Orthop. 1999, 115, 423-428.

[26] Asai Y., Jinno T., Igarashi H., Ohyama Y., Ogawa T.: Detection and quantification of oral treponemes in subgingival plaque by real-time PCR. J. Clin. Microbiol. 2002, 40, 3334-3340.

[27] Choi D.S., Cha B.K., Jost-Brinkmann P.G., Lee S.Y., Chang B.S., Jang I., Song J.S.: Microbiologic changes in subgingival plaque after removal of fixed orthodontic appliances. Angle Orthod. 2009, 79, 1149-1155.

[28] Demling A., Heuer W., Elter C., Heidenblut T., Bach F.W., SchwestKa-Polly R., Stiesch-Scholz M.: Analysis of supra- and subgingival long-term biofilm formation on orthodontic bands. Eur. J. Orthod. 2009, 31, $202-206$.

[29] Atassi F., Awartani F.: Oral hygiene status among orthodontic patients. J. Contemp. Dent. Pract. 2010, 11, 25-32.

[30] van Gastel J., Quirynen M., Teughels W., Coucke W., Carels C.: Longitudinal changes in microbiology and clinical periodontal parameters after removal of fixed orthodontic appliances. Eur. J. Orthod. 2011, 33, 15-21.

[31] Montaldo C., Erriu M., Giovanna Pili F.M., Peluffo C., Nucaro A., Orrù G., Denotti G.: Microbial changes in subgingival plaque and polymicrobial intracellular flora in buccal cells after fixed orthodontic appliance therapy: a preliminary study. Int. J. Dent. 2013, 679, 312.

[32] Nalçaci R., Ozat Y., CokakoĞLu S., Türkkahraman H., Onal S., Kaya. S.: Effect of bracket type on halitosis, periodontal status, and microbial colonization. Angle Orthod. 2014, 84, 479-485.

[33] Ghijselings E., Coucke W., Verdonck A., Teughels W., Quirynen M., Pauwels M., Carels C., van Gastel J.: Long-term changes in microbiology and clinical periodontal variables after completion of fixed orthodontic appliances. Orthod. Craniofac. Res. 2014, 17, 49-59.

[34] Torlakovic L., Paster B.J., Ogaard B., Olsen I.: Changes in the supragingival microbiota surrounding brackets of upper central incisors during orthodontic treatment. Acta Odontol. Scand. 2013, 71, 1547-1554.

[35] BAKa Z.M., BASCIFTCi F.A., Arslan U.: Effects of 2 bracket and ligation types on plaque retention: a quantitative microbiologic analysis with real-time polymerase chain reaction. Am. J. Orthod. Dentofacial. Orthop. 2013, 144, $260-267$.

[36] Ireland A.J., Soro V., Sprague S.V., Harradine N.W., Day C., Al-Anezi S., Jenkinson H.F., Sherriff M., Dyмоск D., SANDy J.R.: The effects of different orthodontic appliances upon microbial communities. Orthod. Craniofac. Res. 2014, 17, 115-123.

\section{Address for correspondence:}

Agnieszka Elżbieta Osmólska-Bogucka

Conflict of Interest: None declared

Department of Orthodontics

Warsaw Medical University

Nowogrodzka 59

Received: 5.10.2015

02-006 Warsaw

Revised: 22.10 .2015

Poland

Accepted: 20.12.2015

E-mail: agabog@mp.pl 